\title{
Clinicopathological correlation of endometrial, myometrial and ovarian pathologies with secondary changes in leiomyoma
} \author{
Pradesh, India.

\section{Keywords: \\ Leiomyoma; Endometrium; Myometrium; Ovary}

Dayal $\mathrm{S}^{1}$, Nagrath $\mathrm{A}^{2}$

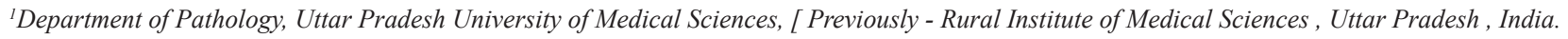
${ }^{2}$ Department of Obstetrics and Gynaecology, Uttar Pradesh University of Medical Sciences, [ Previously - Rural Institute of Medical Sciences , Uttar

\section{INTRODUCTION}

Leiomyoma is the most common, solid, benign monoclonal tumor of smooth muscle. ${ }^{1}$ It is synonymously called

\section{Correspondence:}

Dr. Seema Dayal, MBBS, MD

Department of Pathology, Uttar Pradesh University of Medical Sciences, Saifai, Etawah, Uttar Pradesh, India,

Email: seemadayal77@rediffmail.com

\begin{abstract}
Background: Leiomyomas are the most common benign uterine neoplasm in women of reproductive age group. Uterine leiomyoma are steroid dependent tumors. Leiomyomas are diagnosed by the clinical examination, ultra sound and histopathological examination of the hysterectomy specimens. The aim of this study was to know the clinical symptoms and to diagnose endometrial, ovarian, and other associated coexisting pathologies with leiomyoma and their correlation with leiomyoma.
\end{abstract}

Materials and Methods: Present study was conducted on hysterectomy specimens between January 2008 to 31 December 2015 in the Pathology Department of Rural Institute of Medical Sciences and Research, Saifai, Uttar Pradesh, India. Specimens were grossly examined, sectioned and hematoxylin and eosin stain was applied. Slides were reviewed by pathologist and diagnosis was made.

Results: A total of 437 patients were included. The common age group of patients with leiomyoma was $31-40(42.10 \%)$. Menorrhagia $(60.86 \%)$ was the prime clinical symptom. Among endometrial pathologies and changes, proliferative phase was maximum ( $48.51 \%)$ and endometrial hyperplasia was $(5.03 \%)$. Proliferative phase was seen more with degenerative changes $(42.1 \%)$ and hyaline degenerative was frequent $(15.33 \%)$. Adenomyosis was also seen $(15.10 \%)$. The common pathologies in ovary were simple serous cyst $(6.40 \%)$.

Conclusion: Leiomyoma uteri is a myometrial pathology presenting with clinical symptom of menorrhagia. Proliferative phase, endometrial hyperplasia were common endometrial changes and pathology. Adenomyosis was also common. Chocolate cyst in ovary was also seen which all shows a strong association of hyperestrogenic state being responsible for leiomyoma and all associated pathologies. squamous cell carcinoma were also identified. Among infections Trichomoniasis and candidiasis were seen. 
Table1: Age group of patients diagnosed with leiomyoma

\begin{tabular}{|c|c|c|c|c|c|c|c|c|}
\hline Age & $\begin{array}{c}\text { Under } 20 \\
\text { years }\end{array}$ & 21-30 years & 31-40 years & 41-50 years & 51-60 years & $61-70$ years & $\begin{array}{l}71 \text { years and } \\
\text { above }\end{array}$ & Total \\
\hline No. of patients & $1(0.22 \%)$ & $38(8.69 \%)$ & $184(42.10 \%)$ & $178(40.73 \%)$ & $30(6.86 \%)$ & $5(1.14 \%)$ & $1(0.22 \%)$ & 437 \\
\hline
\end{tabular}

their size, location and hormonal effect. The commonest clinical manifestations are menorrhagia, dysmenorrhoea, abdominal mass, abdominal pain. Leiomyoma need hormonal milieu for their growth and maintenance as evident by the molecular studies that leiomyoma exhibit more estrogen receptors than normal myometrium. ${ }^{3}$ In leiomyoma unopposed estrogenic stimulation manifests commonly as endometrial proliferative phase or hyperplasia. ${ }^{4}$ The clinical diagnosis of myoma is usually based on the finding of an enlarged, mobile uterus with an irregular contour on bi manual examination or an incidental finding on trans abdominal sonography. But ultra sonographics are also only suggestive, the final diagnosis is made by histopathologist. Currently there is insufficient and scanty data regarding associated pathologies in leiomyoma. So, this study was planned to determine the clinical symptoms and coexisting endometrial, myometrial, ovarian and other pathologies which are associated with leiomyoma uteri.

\section{MATERIALS AND METHODS}

This is tertiary care hospital based cross- sectional study carried out in Rural Institute of Medical Science and Research, Saifai, Etawah (Uttar Pradesh) from January 2008 to 31 December 2015. Women who had undergone abdominal, vaginal or laparoscopic hysterectomy with or without salpingo-oophorectomy were included. All the hysterectomy specimens received in the histopathology section of Pathology Department were examined grossly which also included size, weight, location, secondary changes in leiomyoma, status of endometrial polyps and ovarian changes. Endometrial parameters such as thickness of endometrium, phasing, appearance of glands in given area and stromal changes were studied. Formalin fixed hysterectomy specimens were cut, sectioned, and at 3-4 um section were taken. Hematoxylin and eosin stain was applied, if required, additional sections were taken

Table 2: Various clinical complaints of patients diagnosed with leiomyoma

\begin{tabular}{lcr}
\hline Clinical symptom & Number & Percentage \\
\hline Menorrhagia & 266 & $(60.86 \%)$ \\
Metrorrhagia & 80 & $(18.30 \%)$ \\
\hline Polymenorrhagia & 54 & $(11.41 \%)$ \\
\hline Dysmenorrhea & 197 & $(45.08 \%)$ \\
\hline Abdominal mass & 175 & $(40.04 \%)$ \\
\hline Abdominal and Pelvic pain & 132 & $(30.20 \%)$ \\
\hline Miscellaneous & 46 & $(10.52 \%)$ \\
\hline
\end{tabular}

and examined .Other relevant details such as clinical symptoms, menstrual and reproductive factors and history of contraceptive use was also included. Ethical approval was taken from institutional ethical committee.

\section{RESULTS}

A total of 437 patients were included in the study. The common age group among these histopathologically diagnosed leiomyoma uteri was 31-40 years $(42.10 \%$; Table 1). Menorrhagia $(60.86 \%)$ was the prime clinical symptom followed by dysmenorrhea (45.08\%) with abdominal mass (40.04\%), abdominal and pelvic pain (30.20\%) and polymenorrhea (11.41\%). (Table2) Among endometrium pathologies and changes, proliferative phase was more (48.51\%), followed by secretory phase $(29.46 \%)$, endometrial hyperplasia (5.03\%), atrophy (14.18\%), decidual reaction $(0.22 \%)$, endometrial polyp $(1.83 \%)$ and adenomyosis (15.10\%). (Table 3) Secondary degenerative changes were $(32.03 \%)$ of which hyaline degeneration was $(15.33 \%)$. Detail secondary changes in leiomyoma are mentioned in table 4. Common ovarian pathologies were simple serous cyst $(6.40 \%)$, corpous luteal cyst $(4.34 \%)$, follicular cyst $(0.91 \%)$, chocolate cyst $(0.91 \%)$, dermoid cyst $(0.45 \%)$, hemorrhagic cyst $(0.22 \%)$, serous cystadenoma $(0.22 \%)$, fibroma $(0.22 \%)$ and small cell neuroendocrine tumor $(0.22 \%)$ (Table 5$)$.

\section{DISCUSSION}

Leiomyomas are commonest smooth muscle tumors in female genital. These benign tumors occur in $20-40 \%$ female of reproductive age group. ${ }^{5}$ They are steroid dependent tumors. They are typically found during the middle and late reproductive years. Fibroid have not been described in prepubertal girls. In present study maximum no. of cases was seen in 31-40 years $(42.10 \%)$ age group which was consistent with other international revealing that uterine fibroid being more common in third and fourth decade of life. ${ }^{6}$ Reason for that is fibroid are oestrogen dependent thus their usual age distribution is from menarche to menopause.

The symptoms specifically to uterine fibroids are somewhat problematic because of variable clinical presentation and often asymptomatic nature. The symptoms and severity usually depends on size, position, and number of leiomyoma present because symptomatic leiomyomas need urgent attention. Patients with leiomyoma clinically present with dysfunctional uterine bleeding predominantly menorrhagia and pelvic pain. Several studies showed that uterine fibroids 
Table 3: Endometrial, myometrial changes and pathologies with leiomyoma

\begin{tabular}{|c|c|c|c|c|c|c|c|c|}
\hline $\begin{array}{l}\text { Endometri-um and } \\
\text { Pathologies / changes }\end{array}$ & $\begin{array}{l}20 \text { years } \\
\text { and below }\end{array}$ & $\begin{array}{l}21-30 \\
\text { years }\end{array}$ & $\begin{array}{l}31-40 \\
\text { years }\end{array}$ & 41-50 years & $51-60$ & $61-70$ & $\begin{array}{l}71 \text { years } \\
\text { and above }\end{array}$ & Total \\
\hline Proliferative phase & 0 & $13(7.73 \%)$ & $78(46.42 \%$ & $71(42.26 \%)$ & $5(2.97 \%)$ & $1(0.59 \%)$ & 0 & $168(48.51 \%)$ \\
\hline Secreatory phase & 0 & $5(4.85 \%)$ & $52(50.48 \%)$ & $41(39.80 \%)$ & $5(4.85 \%)$ & 0 & 0 & $103(29.46 \%)$ \\
\hline Endometrial hyperplasia & 0 & $4(18.18 \%)$ & $3(13.63 \%)$ & $14(63.63)$ & $1(4.54 \%)$ & 0 & 0 & $22(5.03 \%)$ \\
\hline Atrophy & 0 & $4(6.45 \%)$ & $6(9.67 \%)$ & $14(22.58 \%)$ & $9(12.90 \%)$ & $2(3.22 \%)$ & 0 & $35(8.00 \%)$ \\
\hline Endometritis & 0 & 0 & $4(40 \%)$ & $6(60 \%)$ & 0 & 0 & 0 & $10(2.28 \%)$ \\
\hline Decidua & 0 & 0 & $1(100 \%)$ & 0 & 0 & 0 & 0 & $1(0.22 \%)$ \\
\hline Endometrial polyp & 0 & $1(12.5 \%)$ & $3(37.5 \%)$ & $3(37.5 \%)$ & $1(12.5 \%)$ & 0 & 0 & $8(1.83 \%)$ \\
\hline \multicolumn{9}{|l|}{ Myometrium Pathology } \\
\hline Adenomyosis & 0 & $7(10.60 \%)$ & $27(40.90 \%)$ & $26(39.39 \%)$ & $5(7.57 \%)$ & 0 & $1(1.51 \%)$ & $66(15.10 \%)$ \\
\hline
\end{tabular}

Table: 4 Secondary changes in leiomyoma

\begin{tabular}{lcc}
\hline Secondary changes in leiomyoma & Number & Percentage \\
\hline Hyline Degeneration & 67 & $(15.33 \%)$ \\
Mucoid Degeneration & 34 & $(7.78 \%)$ \\
Cystic Changes & 25 & $(5.72 \%)$ \\
Fatty Changes & 10 & $(2.28 \%)$ \\
Red Degeneration & 4 & $(0.91 \%)$ \\
Total & 140 & $(32.03 \%)$
\end{tabular}

are commonly identified in women who have menorrhagia, pelvic pain, obstructive symptoms, infertility or recurrent pregnancy loss. ${ }^{7}$

Menorrhagia may be due to increased vascularity, increased size of endometrium cavity, altered uterine contractility, increased bleeding surface area, associated endometrial hyperplasia compression of vein by tumor with dilation and engorgement of venous plexus in endometrium and myometrium. ${ }^{8}$

Menorrhagia was $(60.86 \%)$ chief clinical complaint whereas pain was $(30.20 \%)$ which may occur due to pressure effects and degenerative changes. Other least common clinical complaints were painful sexual intercourse, urinary frequency and urgency aggregating $(10.52 \%)$ which may be due to pressure effect.

Endometrium is a tissue which shows structural reorganization with each menstrual cycle in preparation for implantation, in the absence of which superficial layer is partially or completely shed and remodelled in preparation for next cycle. Estrogen and progesterone are hormones required for implantation and maintaining the integrity. Proliferative phase endometrium and secretory phase was accounting (48.51\%) and (29.46\%) respectively. whereas

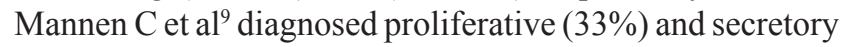
(29\%) phase respectively in their study. The pathogenesis is unexplained. Estrogen stimulation may be important etiological factor. Khan $\mathrm{JS}^{10}$ showed proliferative phase and endometrial hyperplasia both represent estrogen phase and occur due to hyperestrogenic state. Endometrial hyperplasia was aggregating (5.03\%). Endometrial polyp may develop in association with endometrial hyperplasia and is also oestrogen dependent. In the present study endometrial polyp comprised $1.83 \%$.

Atrophy was accounting (14.18\%). It may occur due to mechanical pressure exerted by the nodular mass of the leiomyoma on the overlying or nearby endometrium and also from perimenopausal hormonal insufficiency. Adenomyosis is a myometrial lesion which is characterized by the presence of ectopic endometrial tissue in between fascicles of the myometrium. Coexisting pathologies such as leiomyomata, endometriosis, endometrial hyperplasia, endometrial polyp and endometrial carcinoma are commonly seen with adenomyosis which occurs due to unopposed estrogen. ${ }^{11}$ It was diagnosed in (15.10\%) with leiomyoma.

The secondary or degenerative changes in leiomyoma occur due to inadequate blood supply and interference with the capsular circulation. ${ }^{12}$ Secondary changes in leiomyoma are hyaline , mucoid, cystic, fatty, red, calcification. ${ }^{13}$ Fat cells, skeletal muscle and cartilage have been identified in leiomyoma. Cystic degeneration is the end result of hyaline degeneration. In present hyaline degeneration was a commonly (15.33\%) encountered secondary change, Similar results were seen by Persaud et $\mathrm{al}^{14}$ who also diagnosed hyaline degeneration as a major degeneration in his study. Leiomyoma undergo secondary changes so also adjacent tissue due to estrogenic stimulation. Secondary changes seen in leomyoma was found more with proliferative phase $(42.1 \%)$ which also signify that hyper estrogen state maybe the causative factor. Red degeneration occurs predominantly during pregnancy ${ }^{15}$ because of hormonal influence. We also diagnosed red degeneration $(0.91 \%)$ in leiomyoma along with pregnancy.

Ovarian pathologies are seen with leiomyoma in $13.72 \%$ of total cases. Simple serous cyst was the most common ovarian pathology $(6.40 \%)$. It is commonly and possibly 
Table 5: Ovarian pathologies in patients with leiomyoma

\begin{tabular}{|c|c|c|c|c|c|c|c|c|}
\hline Ovarian pathology & $\begin{array}{l}20 \text { years } \\
\text { and below }\end{array}$ & $\begin{array}{l}21-30 \\
\text { years }\end{array}$ & 31-40 years & 41-50 years & 51-60 years & $61-70$ years & $\begin{array}{l}71 \text { years } \\
\text { and above }\end{array}$ & Total \\
\hline Simple serous cyst & 0 & $1(3.57 \%)$ & $8(28.57 \%)$ & $17(60.71 \%)$ & $2(7.14 \%)$ & 0 & 0 & $28(6.40 \%)$ \\
\hline Corpous leutial cyst & 0 & $1(5.26 \%)$ & $10(52.63 \%)$ & $7(36.84 \%)$ & $1(5.26 \%)$ & 0 & 0 & $19(4.34 \%)$ \\
\hline Follicular cyst & 0 & 0 & $1(25 \%)$ & $3(75 \%)$ & 0 & 0 & 0 & $4(0.91 \%)$ \\
\hline Chocolate cyst & 0 & $3(75 \%)$ & $1(25 \%)$ & 0 & 0 & 0 & 0 & $4(0.91 \%)$ \\
\hline Dermoid cyst & 0 & 0 & 0 & $2(100 \%)$ & 0 & 0 & 0 & $2(0.45 \%)$ \\
\hline Serous cyst adenoma & 0 & 0 & 1 & 0 & 0 & 0 & 0 & $1(0.22 \%)$ \\
\hline Fibroma & 0 & 0 & 0 & 1 & 0 & 0 & 0 & $1(0.22 \%)$ \\
\hline $\begin{array}{l}\text { Small cell neuro endo } \\
\text { crine tumor }\end{array}$ & 0 & 0 & 0 & 1 & 0 & 0 & 0 & $1(0.22 \%)$ \\
\hline Total & & & & & & & & $60(13.72 \%)$ \\
\hline
\end{tabular}

significantly association with leiomyoma are follicular cyst of ovary, endometrial hyperplasia, endometrial carcinoma and endometriosis. ${ }^{11}$ Follicular cyst and leiomyoma have equal incidence. ${ }^{16}$ In present study similar results were not seen because follicular cyst was found $(0.91 \%)$ in association with Leiomyoma . In this study chocolate cyst of ovary was seen in $0.91 \%$ of cases. In endometriosis as a result of repeated hemorrhages, ovary is converted into a chocolate cyst which again shows a strong association with hyper estrogenic state. ${ }^{12}$

\section{CONCLUSION}

Leiomyoma is common pathology seen predominantly in late reproductive and perimenopausal women which clinically present with menorrhagia. Proliferative phase, secretory phase, endometrial hyperplasia were common endometrial changes and pathologies seen with leiomyoma whereas in myometrium adenomyosis was also frequent. Leiomyomas undergo secondary changes due to estrogenic stimulation. Simple serous cyst was common ovarian pathology but follicular cyst, chocolate cyst was also encountered which again signifies a strong association of leiomyoma with hyper estrogenic state.

\section{REFERENCES}

1. Crum CP. Body of uterus and endometrium. In : Kumar V, Abbas AK, Fauston, Eds. Robbins and cotran Pathologic basis of disease. 7th ed, Philadelphia: Saunders, 2004.pp 1089- 90.

2. Zimmermann A, Bernuit D, Gerlinger C. Prevelance, symptoms and management of uterine fibroid an international internet based survey of 21, 746 women. BMC women health.2012;12:6.

3. Rein MS, Barbieri RL, Fried man AJ. Progesterone: A critical role in pathogenesis of uterine myomas. Am J Obs \& Gynecol 1995;172:148. Crossref

4. Witherspoon TJ. The interrelationship between ovarian follicle cysts, hyperplasia of the endometrium and fibromyomata. Surg Gynecol
Obstet 1933;56:1026 -35.

5. Anderson MC . Female genital tract. In: Symmer SW editor, systemic pathology . 3rd edition . Edinburg; Churchill living stone: 1991. pp284-312.

6. Lefebure G, Viols G, Allaire C. The management of uterine leomyoma : clinical practice . Gynecological committee . Obstet Gynecol Can 2003: 5:396-418.

7. Ibrar F, Raiz S, Dawood NS. Frequency of fibroid uterus in multiparous women in a tertiary care centre in Rawal pindi . J Ayub med Coll Abbottabad 2010;22:155-7. Crossref

8. Gowri M, Mala G, Murty G, Nayak V. clinicopathological study of uterine leiomyomas in hysterectomy specimens. Journal of Evolution of medical and Dental Sciences 2013;2: 9003-9. Crossref

9. Chethana M, Kumar H, Muni Krishna M. Endometrial changes in uterine Leiomyomas. J Clin Bio Med Sci 2013;3:72-9.

10. Jargal Sai Khan B, Galtrog L, erdenetrogt D, Yanjinsuren D. Endometrial epithelial changes associated with uterine Leiomyoma. Mongolian Journal Of Health Sciences 2013;1:1-7.

11. Dayal S, Nagrath A. Pattern and frequency of Endometrial and ovarian pathologies with Adenomyosis Uteri in Patients who attended the tertiary care hospital among Rural population of North India . MAMC Journal of Medical Sciences 2015;1:147-50. Crossref

12. Padubidri VG, Daftary SN. Fibromyomas of the uterus. Howkin's \& Bourne shaw's Textbook of Gynaecology, 12th ed, New Delhi; Churchill living stone:1999.pp275-85.

13. Juan Rosai. Rosai and Ackerman's Surgical Pathology. Mosby. 9th Edition. 2005.2892p.

14. Persaud V, Arjoon PD. Uterine Leiomyoma. Incedence of degenerative change and correlation of associated symptoms. Obstet Gynecol. 1970; 35:432-6. Crossref 
15. Prayson RA, Hart WR. Pathological considerations of uterine smooth muscles tumors . Clin N America 1995;22:637-57.
16. Kumar P, Malhotra N. Tumors of the corpus uteri. Jeffcoates Principals of Gynecology, 7th ed. 2008.pp 487-520. Crossref 